\title{
Entrepreneurship Development through Rural Bio-Resource Complex with Adoption of Integrated Farming with Mushroom, Aquaculture, Organic Farming and Value Addition in North Bengal Region of West Bengal
}

\author{
A. K. Chowdhury ${ }^{\text {* }}$, P. M. Bhattacharya ${ }^{1}$, A. Roy ${ }^{1}$, S. Bandyopadhayay ${ }^{1}$, \\ B. N. Chakraborty ${ }^{2}$, Usha Chakraborty ${ }^{2}$ and A. S. Ninawe ${ }^{3}$ \\ ${ }^{1}$ Department of Plant, Pathology, Uttar Banga Krishi Viswavidyalaya, Pundibari, \\ Coochbehar, West Bengal, India \\ ${ }^{2}$ Department of Botany, University of North Bengal, West Bengal, India \\ ${ }^{3}$ Department of Biotechnology, CGO Complex, Lodhi Road, New Delhi, India \\ *Corresponding author
}

\section{Keywords \\ Rural Bio-resource Complex, Capacity development, Income generation, Livelihood \\ Article Info \\ Accepted: \\ 15 October 2020 \\ Available Online: \\ 10 November 2020}

\section{A B S T R A C T}

\begin{abstract}
Indian farming has been suffering due to indiscriminate application of chemical fertilizers and pesticides and due to lack of farm based integrated farming based interventions. Further, the monocropping pattern also one of the major factors that have contributed for disinterest and apathy among farmers. The indiscriminate increase in cost of production, lack of assured market, price fluctuations and fragmentation of land holdings, timely non availability of critical inputs and also decline in soil productivity due to lack of science and technology inputs in farming system are the serious concerns which affects farmers' economy. This has resulted in loss of soil fertility, productivity of crops as well as hazards to human health. According to the feedback from several quarters, farmers in general and farm youth in particular, are losing confidence in farming. More than 40 per cent of farming families want to leave farming in India. In a progressive state like Punjab also where the farmers are relatively well assured with resources compared to majority of other states in the country farmers are losing their confidence in farming. Therefore, it is difficult to imagine the mindset of farmers in other parts of the country. The situation is more or less same in many developing as well as few developed countries. Therefore, a network project was undertaken with the support of the Department of Biotechnology, Government of India on establishment of rural bio-resource complex in North Bengal implemented by University of North Bengal and Uttar Banga Krishi Viswavidyalaya in seven districts viz, Darjeeling, Jalpaiguri, Cooch Behar, Alipurduar, Uttar Dinajpur, Dakshin Dinajpur and Malda in West Bengal State. By understanding the importance of organic farming and introduction of high value crops, interventions on mushroom cultivation, aquaculture and solid waste management were taken up in the districts benefitting more than 2000 farmers including Self Help Groups. The details have been highlighted in the paper.
\end{abstract}

\section{Introduction}

Global emphasis is on organic cultivation is being promoted for adoption of organic farming and to provide an alternative solution to chemical farming. Government of India published report in 2015, stated that the domestic organic food market would touch 
$\$ 1.36$ billion by 2020 and the market is growing at 25-30\% (Kavitha and Krishnaveni, 2016). By understanding the importance of organic farming and introduction of high value crops, interventions on mushroom cultivation, aquaculture and solid waste management were taken up in seven districts of Northern parts of West Bengal.

The project was implemented in seven districts of West Bengal namely; Darjeeling, Jalpaiguri, Cooch Behar, Alipurduar, Uttar Dinajpur, Dakshin Dinajpur and Malda. The criteria for selection of districts was dominance of backward communities due to absence of any industry and limited livelihood options, dependence only on traditional agriculture. To address the region based issue, a project on establishment of rural bioresource complex in North Bengal was initiated in the region during 2011-2016 supported by Department of Biotechnology, Government of India. The project was based on the management of the rich bio-resources of North Bengal region and their sustainable use through biotechnological intervention and development of innovative technologies for socio-economic growth and upliftment of the rural populations in this state.

\section{Materials and Methods}

Demographically, North Bengal Zone is comparatively backward in terms of education, agriculture development and lack of heavy industries. The livelihood of the people depends on age-old agriculture practices but immense scope exist to improve the livelihood due presence of rich bioresources. The Northern parts of West Bengal fall in between $24^{0} 40^{\prime} 28^{\prime \prime}-27^{\circ} 13^{\prime} \mathrm{N}$ and $87^{0} 45^{\prime} 50^{\prime \prime}-89^{0} 54^{\prime} 35^{\prime \prime} \mathrm{E}$.

The project implementation sites are located in between different countries like
Bangladesh in the East, Nepal and Bhutan in the North. The presence of Uttar Banga Krishi Viswavidyalaya (UBKV) and University of North Bengal (NBU) has made impact in the community in this zone. These two coordinating and implementing agencies have created effective linkages with local research organizations, development departments, commodity boards and the financial institution.

At both the implementation sites demonstration and training activities were conducted. The interventions on mushroom cultivation and processing centre at village level, dissemination of techniques for sustainable solid waste management through vermicomposting, use of bio-fertilizers and bio-control agents, establishment of aquaculture units in adapted villages for quality seed production and economically important fishes and ultimately human resource development were taken up.

These activities were taken up to benefit farmers, rural women and unemployed youths in seven district of North Bengal for sustainable utilization of biological resources through awareness and popularization activities. project implementation area of North Bengal regions.

While taking up the project for implementation by NBU and UBKV in collaboration with local KVKs/NGOs details on population data on income and living standard of the families were collected. The baseline information collected were analyzed and documented for the entire families in all the seven districts in North Bengal region and the community participation were selected mostly agrarian based and socio-economically weaker. The packages of interventions selected were introduced on organic farming with enrichment of vermicomposting with bio-fertilizers/bio-control agents/bio- 
pesticides (Rajasekhar et al., 2012) mushroom cultivation. Emphasis was also given on year long seasonal production of different varieties and integrated fish farming with prawn culture and cultivation of local fish verities.

\section{Work component I (Mushroom Cultivation)}

In North Bengal mushroom cultivation is very popular and highly adopted intervention at the community level due to favourable environmental conditions, climate and temperature for cultivation of different types of mushrooms (Button mushroom, Oyster mushroom, Milky mushroom etc.). It also produces round the year and an important food item concerning human health, nutrition and disease prevention.

Button mushroom: Agaricus bisporus commonly known as button mushroom is mainly cultivated on the hills as it requires low temperature for its growth; however with the advent of modern cultivation technology it is now possible to cultivate under controlled conditions throughout the year. In North Bengal, formerly its production was limited in winter season, but now it is cultivated throughout the year adopting different levels of technology developed by the project. Demand of white button mushroom is now increasing in North Bengal and farmers are now getting a very high market price.

Oyster mushroom: Pleurotus sp. is one of the common mushrooms cultivated throughout the North Bengal. But in the absence of scientific cultivation process, project cultivators have standardized its cultivation practices by using wide range of locally available substrates which are being widely adopted by the farmers of this zone and training on post harvest processing has also be given.
Milky mushroom: The cultivation practices of Calocybe indica have been introduced through the project activities and farmers are slowly adopting the technology during summer months.

\section{Work component II (Solid waste management and vermicomposting)}

Dissemination techniques for solid waste management was being imparted to interested persons of the command areas have been given training on preparation of vermicompost using the locally available agro-waste as well as using the by-product of mushroom cultivation (i.e. spent mushroom substrate). Target farmers of the command area of the project have been given training on seedling and crop production technology for getting more number of transplantable seedlings. The training on soil solarisation (polythene mulching), use of insect nets (agro-shade nets), use of beneficial microbes through the organic matter (value addition), opting for containerized seedling production (protrays) and use of spent mushroom substrate for vermicomposting were conducted.

\section{Work component III (Aquaculture/fish culture)}

Hands on training and demonstration programme on induced breeding of Asian Magur, Koi fish were conducted. Training on induced breeding of Asian Magur, carp, cat fish and Ornamental fish and their disease management were provided to 737 farmers including 150 women. The project activities were implemented through Farmers Clubs, Local level NGOs, Women Self- help Groups etc. The concerned organisation was approached for capacity development on areas of intervention and linking them to market channel. 


\section{Results and Discussion}

The interventions undertaken on solid waste management, oyster mushroom cultivation and fish culture were highly popular among the rural communities and therefore, choice based interventions were selected. It has created great impact among the farming community. The partnership with local NGOs and KVKs has created strong bounding and networking in the project implementation in which more than 2000 people have been trained in different interventions. The details of the trained beneficiaries have been depicted in Fig. 1 and 2. The target community trained learns the technologies by observing the demonstrations and then by doing the same on their own.

Around 50 entrepreneurs have been created who have been able to establish their business units. The interventions on identification of most profitable, sustainable and location specific technologies were taken up for easy reach of rural people, providing critical inputs free of cost at the easy access, effective functional linkage, marketing empowerment and commodity based associations.

In the project three interventions were seriously carried out viz. Mushroom cultivation, solid waste management and fish culture including value addition aspects. During the cultivation season mushrooms were very highly productive. However, due to unavailability of technologies for proper storing, drying and preparation of postharvest products and being perishable, there is lot of wastage. Spent mushroom substrate remaining after a crop of mushrooms is highly rich in organic matter making desirable for use as a soil amendment or soil conditioner is being used for water holding capacity, soil $\mathrm{pH}$, soil porosity, salt content i.e. electrical conductivity and other important properties. Addition of Spent Mushroom Substrate
(SMS) add great amount of macronutrient like nitrogen, phosphorous and potassium (NPK) in the culture system. The possibility of SMS as carrier for bio-control agents and biofertilizers was explored as an alternative outlet for SMS.

Solid Waste Management and vermicomposting have been promoted for enhancement of farm inputs as organic concept through use of value addition in farming by addition of microorganisms such as Trichoderma, rhizobacteria (phosphate solubilizers and/or nitrogen fixers), arbuscular mycorrhiza (nutrient mobilizers) etc. which can accelerate growth and productivity of crops in a completely organic manner. This has been promoted as second intervention as solid waste management in farming for sustainable agriculture.

Fish farming is very much appealing for North Bengal region. High value fishes like Catla, Rohu including prawn and air breathing fishes are being promoted for having more fish productivity. These interventions were provided to supplement protein rich food for malnourishment by popularizing fresh water fish culture in the backyard ponds of the beneficiaries.

The detail cost benefit analysis of the interventions namely mushroom production its sale proceeds, cost benefit analysis of solid waste management/ vermicomposting and fish culture production are provided in the Tables 1, 2 and 3.

The production of different mushrooms yearwise and district-wise has been presented in Figs. 3 and 4.

An NGO, Landesa having expertise with training of girl students in West Bengal was involved for imparting large training activities and the activities were linked with District 
Rural Development Corporation and NABARD for development of infrastructure in rural community. All the three different components, mushroom, vermicomposting, aquaculture was taken up. Women Self Help Groups and Farmers Club were involved. In the project, 3025 local entrepreneurs have been created who have successfully adopted mushroom cultivation, vermicomposting, fish farming and product development through value addition. In the DBT RBC project implemented by the University of Agricultural Sciences, Bangalore during 2005-2010, the improvement of the income and standard of living of the families engaged from 75 villages of five panchayats in a contiguous area in Karnataka benefitted through cultivating traditional crops realising 60 percent of the potential yield. The project was successful in rainfed area and could help in bringing significant changes in productivity, income and employment generation with considerable influence on standard of living. The studies undertaken through implementation of RBC project at UAS created good impact through establishment of technology resource centre and farm based infrastructure with adoption of various interventions of Agriculture, Horticulture, Farm-based technology with Animal Husbandry, Agro-processing and Value Addition (Narayana Gowda, 2009). DBT has conducted an impact assessment of Rural Bio-resource Complex through an agency Mott MacDonald, Noida, Uttar Pradesh, indicated that the beneficiaries practicing two crops in a year, and even more per year has shown good increase of profit with the intervention supported through trainings and demonstration activities and the entrepreneurs adopted interventions in integration started earning attractive income (Anon, 2010).

Table.1a Cost-benefit of different types of mushroom

\begin{tabular}{|l|c|c|c|c|c|}
\hline \multicolumn{1}{|c|}{ Mushroom } & $\begin{array}{c}\text { Cost / Bag } \\
\text { (Rs.) }\end{array}$ & Production /Bag & $\begin{array}{c}\text { Sale price in } \\
\text { Rs/kg }\end{array}$ & $\begin{array}{c}\text { Net profit in Rs/ } \\
\text { Bag }\end{array}$ & Time period \\
\hline Agaricus bisporus & 66.00 & $1.5 \mathrm{~kg}$ & 260.00 & 324.00 & $75-85$ days \\
\hline Calocybe indica & 39.00 & $500 \mathrm{gm}$ & 120.00 & 81.00 & 45 days \\
\hline Pleurotus mushroom & 40.00 & $1 \mathrm{~kg}$ & 80.00 & 40.00 & 30 days \\
\hline
\end{tabular}

Table.1b Cost-Benefit ratio of different edible mushrooms

\begin{tabular}{|l|c|c|c|}
\hline \multirow{2}{*}{ Month } & \multicolumn{3}{|c|}{ Sale price of mushroom } \\
\cline { 2 - 4 } & Oyster mushroom (Rs.) & Button mushroom (Rs.) & Milky mushroom (Rs.) \\
\hline February & 60.00 & 260.00 & 130.00 \\
\hline March & 70.00 & 260.00 & 140.00 \\
\hline April & 70.00 & 260.00 & 140.00 \\
\hline May & 80.00 & 300.00 & 150.00 \\
\hline June & 90.00 & 300.00 & 150.00 \\
\hline July & 80.00 & 300.00 & 120.00 \\
\hline August & 90.00 & 300.00 & 120.00 \\
\hline September & 120.00 & 300.00 & 120.00 \\
\hline October & 100.00 & 300.00 & 120.00 \\
\hline November & 80.00 & 300.00 & 120.00 \\
\hline December & 70.00 & 280.00 & 150.00 \\
\hline
\end{tabular}


Table.2 Average Sale price of different edible mushrooms in different times of year in North Bengal

\begin{tabular}{|l|c|c|c|c|c|c|}
\hline Item & Production & Cost (Rs.) & Sale price/kg & Net profit & Time period & C:B ratio \\
\hline Vermicompost & $20 \mathrm{q}$ & 80000.00 & 9.00 & 100000.00 & Annual & $1: 1.25$ \\
\hline $\begin{array}{l}\text { Bio-primed } \\
\text { seedlings }\end{array}$ & 5000 nos & 1500.00 & $1.00 /$ seedling & 3500.00 & Quarterly & $1: 2.33$ \\
\hline
\end{tabular}

Table.3 Cost benefit analysis of aquaculture in rupees

\begin{tabular}{|l|c|c|c|}
\hline \multicolumn{2}{|c|}{ Inputs } & Expenditure & Income \\
\hline \begin{tabular}{l|c|c|} 
Mature female and \\
male fish
\end{tabular} & $10 \mathrm{~kg}$ & 8000.00 & $\begin{array}{c}\text { Sale of fingerlings } \\
\text { @ Rs. 4 .00 hatchling }\end{array}$ \\
\hline Hormone & $\begin{array}{c}\text { 5 vial (400/- } \\
\text { per vial) }\end{array}$ & 2000.00 & $\begin{array}{c}\text { Expenditure } \\
\text { C:B Ratio: } 1: 2.33\end{array}$ \\
\hline Hatching tray & 5 Nos. & 5000.00 & \\
\hline $\begin{array}{l}\text { Fish feed (artemia, } \\
\text { tubifex) }\end{array}$ & - & 10000.00 & \\
\hline Others & - & 5000.00 & Profit- Rs.70000.00 \\
\hline Total & - & 30000.00 & \\
\hline
\end{tabular}

Fig.1 Total number of trainees trained in different components of the project

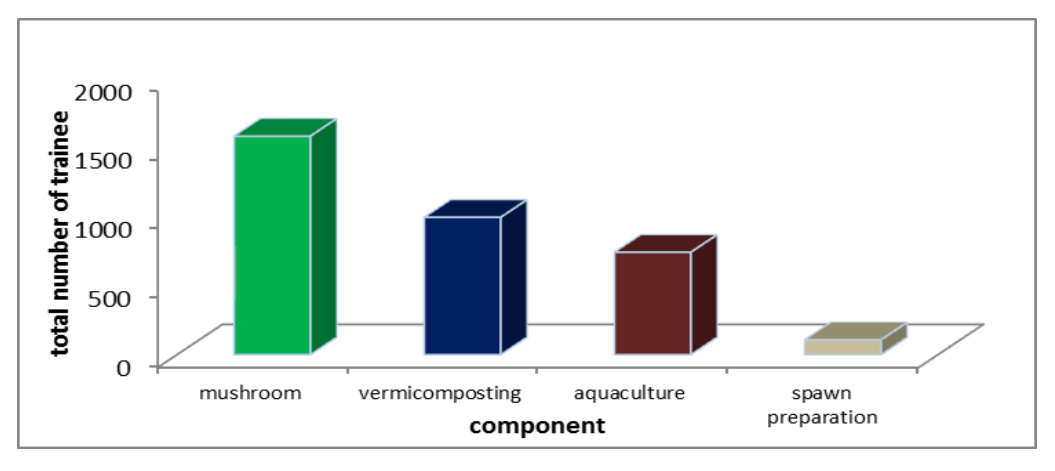

Fig.2 Year wise depiction of trainees trained in different components

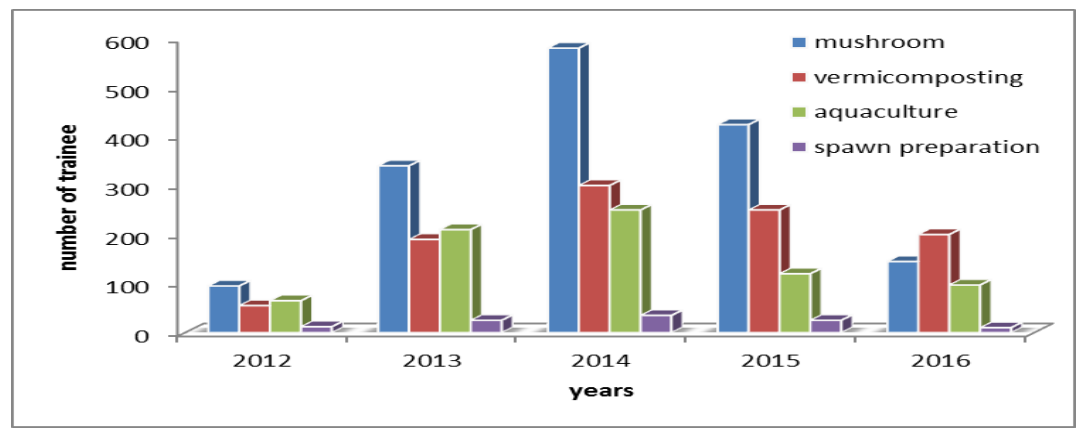


Fig.3 Production of three different mushrooms during the period of 2012-2016

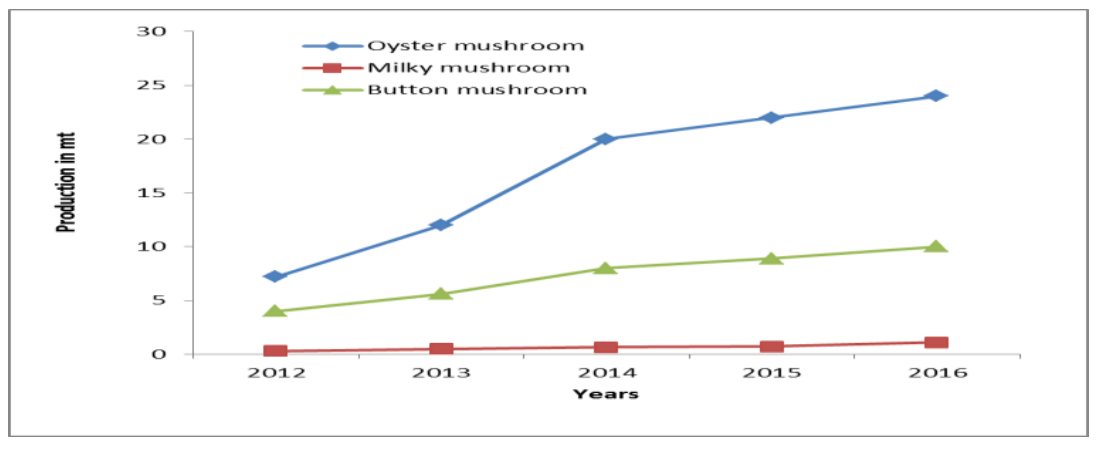

Fig.4 Comparison of mushroom production in different districts of North Bengal

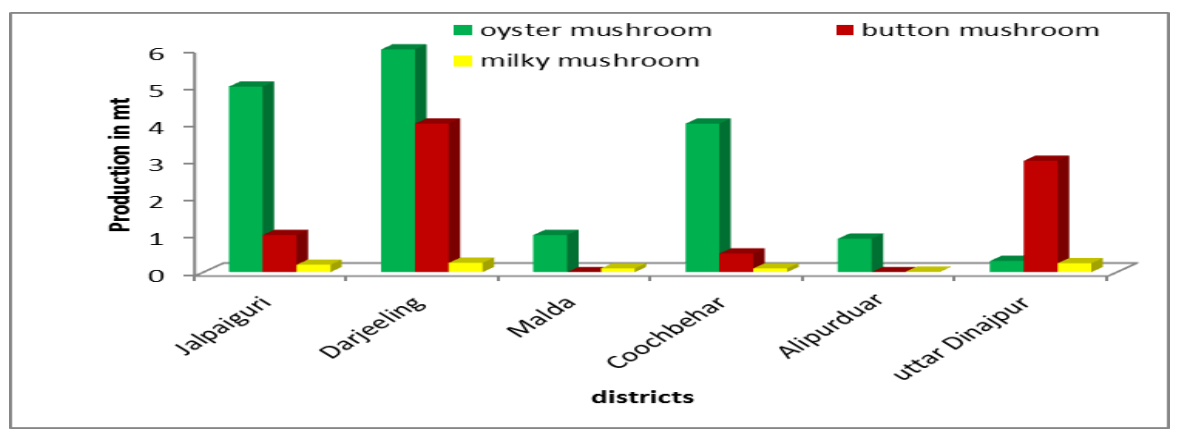

In the project, the achievements were possible with the contribution of six important factors namely; identification of most profitable, sustainable and location specific technologies, timely and dependable information at the easy reach of rural people, providing critical inputs free of cost at the easy access, effective functional linkage, marketing empowerment and commodity based associations. To achieve this the demonstration and training activities undertaken on mushroom cultivation has covered 300 beneficiaries with setting up of spawn production and mushroom cultivation units and training of 2013 persons of which 432 nos. are women in Coochbehar, Malda, Jalpaigiuri, North and South Dinajpur and Darjeeling districts. 149 mushroom production units have been established by the beneficiaries at Coochbehar, Jalpaiguri, Darjeeling and Malda districts and 11 spawn production units were developed at Coochbehar, Jalpaiguri, Darjeeling and Malda.
In solid waste management 946 persons were trained including 167 nos of women. The trained people have set up commercial units of vermicompost and 21 demonstrative trials have been conducted with the bio-agents supplied to Govt. and NGOs for farming. The value addition of nitrogen fixers (Rhizobium, Azotobacter, Azospirillum, blue green algae); plant growth promoting rhizobacteria (Bacillus, Pseudomonas) and biocontrol agents (Trichoderma, arbuscular mycorrhizal fungi) with vermicompost stimulated growth and development of plants.

In aquaculture hands on training and demonstration programmes helped in induced breeding of Asian Magur, Koi fish. Training on induced breeding of Asian Magur, carp, cat fish and Ornamental fish and their disease management were provided to 737 farmers including 150 women. The project activities were implemented through Farmers Clubs, Local level NGOs, Women Self-help Groups 
etc. The participating organisations approached for market linkages after capacity building in different interventions undertaken.

In conclusion the project also encompasses the development of small entrepreneurs in the field of mushroom production, aquaculture and vermicomposting as an alternative strategy for maximizing rural revenue through agricultural waste management. The assessment and proper utilization of natural resources have benefitted the target farmers with extra inputs for agriculture leading to sustainable and profitable production.

Bio-resource Centre has act as a single window for the farmers providing them with improved technologies for improvement of their livelihood through trainings, demonstration and products. The target population of the project (farmers, rural women, unemployed youths etc.) from seven districts of North Bengal under the jurisdiction of UBKV and NBU was directly involved in the demonstrations on the intervening areas. Upon receiving practical experience from there, they started practicing the same in their own farm lands at the same time. Constant monitoring of their performance was done to encourage them and suggestions to any problem were provided.

The economy of the area hinges upon agriculture and therefore crop based agriculture is the only occupation of the people in the area. The advantages of improved package of practices have not yet reached to the target population. This is due to lack of approach on the part of various agencies, demonstrating the usefulness and feasibility of modern technologies to them. Another factor is the marginal nature of the farm holds and poor economic status of the people which do not allow them to venture into the modern package of practices which involved procurement of even small implements and machineries needed for this. The programme implemented on production of mushroom generates income to the farm families during the lean seasons. It has also provided cheap and protein rich vegetarian diet to the people and has been the very viable intervention for the marginal farmers who are landless. The cultivation of quality fingerlings which are not locally available provides to generate income to the nursery owner as well as the cultivators. Expertise development on ornamental fish culture has explored good potential in this area and opened avenues for youth. This has created a path for the local farmers to adopt fisheries also as an economic enterprise. Establishing marketing linkages created to help farmers to realize profit, direct sale by producers. Many farmers /Farm women/Farm youth were encouraged to undertake sale of produces by themselves particularly, vermicomposting, fish and mushroom.

The programme implemented was evaluated through pre-and post-assessments of the technology introduced. Beside this, the demand for bio-inoculants and mushroom master spawn has increased significantly during the four years. During the project period, 9 commercial vermicompost units and 10 mushroom villages have been developed in this area. Regarding production of fingerlings by the farmers/ local entrepreneurs, atleast one unit has been developed in three districts. The successful local entrepreneurs have been created through this programme with the rural bio-resource complex utilizing sustainable bio-resources from the region which were resource based for exploitation and exploration.

\section{Acknowledgement}

The Authors are thankful to the Department of Biotechnology, Ministry of Science and Technology, Government of India for funding 
the field based activities under the Rural BioResource Complex.

\section{References}

Anon.2010. An impact Assessment of Rural Bio-resource Complex, DBT Assessment Report by Mott MacDonald, Noida, Uttar Pradesh, pp 1-153.

Kavitha,M. S. and Krishnaveni, K. M. 2016. Problems and prospects of organic food market in India - An overview; International Multidisciplinary Research
Journal; Indian Streams Research Journal; 6(7).p5.

Narayana Gowda K. 2009. Rebuilding the Confidence of Farmers- Experiences of an Innovative Extension Project. Indian Res. J. Ext. Edu. 9 (3), 6-8.

Rajasekhar K, Daniel T and Karmegam M. 2012. Microbial enrichment of vermicompost. ISRN Soil Science, Volume 2012, Article ID 946079, pp13 http://dx.doi.org/10.5402/2012/946079.

\section{How to cite this article:}

Chowdhury, A. K., P. M. Bhattacharya, A. Roy, S. Bandyopadhayay, B. N. Chakraborty, Usha Chakraborty and Ninawe, A. S. 2020. Entrepreneurship Development through Rural BioResource Complex with Adoption of Integrated Farming with Mushroom, Aquaculture, Organic Farming and Value Addition in North Bengal Region of West Bengal. Int.J.Curr.Microbiol.App.Sci. 9(11): 1797-1805. doi: https://doi.org/10.20546/ijcmas.2020.911.213 